\title{
Mixed-ligand complexes of gadolinium carboxylates containing unsaturated bonds in plastic scintillators
}

\author{
E.S.Velmozhnaya, A.I.Bedrik, P.N.Zhmurin, \\ D.S.Safronov, A.G.Doroshenko
} Institute for Single Crystals, STC "Institute for Single Crystals", National
Academy of Sciences of Ukraine, 60 Lenin Ave., 61001 Kharkiv, Ukraine

Received April 8, 2015

Results are presented on properties of new synthesized Gd-carboxylates with unsaturated bonds. Gd-containing polystyrene oligomer and plastic scintillators based thereon were obtained using these compounds. The chemical structure of the synthesized compounds was characterized by the IR spectroscopy. Thermographic properties of new complexes were investigated. It is shown that thermal stability of the gadolinium complexes significantly increases with introduction of the unsaturated moiety into their structure and reaches at about $300^{\circ} \mathrm{C}$. The solubility of these structures remains practically unchanged with respect to complexes that do not contain unsaturated bonds. The light output of the obtained Gd-loaded material (plastic scintillators) is kept sufficiently high and reaches $78 \%$ with respect to the unloaded sample.

Keywords: Gd-loaded plastic scintillators, gadolinium carboxylate, complex, oligomer, light yield.

Представлены результаты исследований свойств новых синтезированных карбоксилатов гадолиния, структура которых содержит непредельный фрагмент. С использованием этих соединений получен гадолинийсодержащий полистирольный олигомер и пластмассовые сцинтилляторы. Строение карбоксилатов подтверждено данными ИКспектроскопии. Исследованы термографические свойства новых комплексов. Показано, что с введением непредельного фрагмента термическая устойчивость значительно повышается и достигает $300^{\circ} \mathrm{C}$. Растворимость таких структур остается практически неизменной по отношению к комплексам, не содержащим непредельных связей. Световой выход пластмассовых сцинтилляторов сохраняется достаточно высоким и достигает $78 \%$ по отношению к незагруженному образцу.

Змішані карбоксилати гадолінію, що містять ненасичений фрагмент в пластмасових сцинтиляторах. О.С.Вельложна, А.І.Бедрик, П.М.Жмурін, Д.С.Сарронов, А.Г.Дорошенко.

Представлено результати досліджень властивостей нових синтезованих карбоксилатів гадолінію, структура яких містить ненасичений фрагмент. 3 використанням цих сполук отримано гадолінійвміщуючий полістирольний олігомер і пластмасові сцинтилятори. Їх будову підтверджено даними ІЧ-спектроскопії. Досліджено термографічні властивості нових комплексів. Показано, що 3 введенням ненасиченого фрагмента термічна стійкість значно підвищується і досягає $300^{\circ} \mathrm{C}$. Світловий вихід пластмасових сцинтиляторів зберігаєтся достатньо високим і досягає 78 \% у відношенні до незавантаженого зразку. 


\section{Introduction}

Carboxylate derivatives of rare earths elements (REE) occupy a special place among the metal-containing monomers, in particular, compounds of unsaturated carboxylic acids [1]. These compounds contain a double bond that can be opened for polymerization and a metal ion that is chemically bonded with organic part of the molecule.

Up till now, the study of polymerization processes of such monomers have been intensively developed because of substantial practical value of the resulting products and their compositions.

Plastic scintillators (PS) containing heavy metals can be used for registration of various types of radiation [2]. Previously, we reported the synthesis and uses of carboxylates of aliphatic-aromatic acids as gadolinium-containing compounds [3,4]. These compounds, which are highly soluble in styrene, allowed us to obtain polymers with satisfactory properties. Such carboxylates exist in the form of solid solutions. It was of interest to us to synthesize and introduce into a polystyrene base unsaturated compounds of gadolinium. This would provide an opportunity to get more stable chemically bounded gadolinium-containing polymers.

A detailed analysis of the synthesis methods of unsaturated metal carboxylates is done in [1].

It should be noted that we attempted to synthesize gadolinium methacrylate and introduce it into polystyrene. But we could not achieve the desired results, because this substance was high-melting $\left(>300^{\circ} \mathrm{C}\right)$ and practically insoluble in polystyrene. Therefore, there was an idea of synthesizing such a structure that would include a well-known aliphatic-aromatic moiety and a residue of unsaturated acids. This could provide a good solubility for the complex that would be chemically bonded with the polymer, and the styrene oligomer complex would act as a "seeding agent" in the polymerization process of styrene.

\section{Experimental}

There is a wide variety of synthesis methods of mixed metal salts [5]. The paper [6] presents a synthesis of the mixed gadolinium salt where the methacrylate ligand is gradually replaced by propionic or isobutyric acids fragments. The method of synthesis of Gd-carboxylate starting from a metal alkoxide and mixtures of methacrylic and isobutyric acids is also described there. The nature of the metal alkoxide and the molar ratio of organic acid and alkoxide are the main factors that allow efficient control of the structure and size of the formed molecules.

Syntheses of heterometallic carboxylates containing ions of rare earth elements are widely represented in [7-10].

Synthesis of Gd-carboxylates that we are interested in was carried out under anhydrous solvent using the authors' technique [11].

The first step is to obtain a base gadolinium salt of the corresponding acid. A freshly prepared gadolinium hydroxide reacted with equimolecular amount of 4phenylbutyric or 4-phenylvaleric acid in dry toluene (Scheme 1).

In the second step of obtaining the $\mathrm{Gd}$ complex including aliphatic-aromatic ligands of unsaturated acid, the formed base salt reacts with methacrylic or 4-vinylbenzoic acids (Scheme 2).

In the third step the mixed salt was reacted with a neutral ligand - triphenylphosphine oxide (TPPO) [12]. These molecules always require saturation of the gad-

$$
\mathrm{Gd}(\mathrm{OH})_{3}+\prod_{\mathrm{O}}^{\mathrm{R}_{1}, \mathrm{R}_{2}} \stackrel{\mathrm{OH}}{\stackrel{\text { toluene }}{\longrightarrow}}
$$

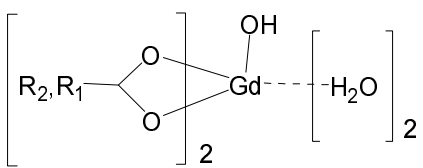

Scheme 1. $\mathrm{R}_{1}=\mathrm{C}_{6} \mathrm{H}_{5}-\left(\mathrm{CH}_{2}\right)_{3}-; \mathrm{R}_{2}=\mathrm{C}_{6} \mathrm{H}_{5}-\left(\mathrm{CH}_{2}\right)_{4}-$.

$$
\left[\mathrm{R}_{2}, \mathrm{R}_{1}\right.
$$

Scheme 2. $\mathrm{R}_{3}=-\left(\mathrm{CH}_{3}\right) \mathrm{C}=\mathrm{CH}_{2}, \mathrm{R}_{4}=-\mathrm{C}_{6} \mathrm{H}_{4}-\mathrm{CH}=\mathrm{CH}_{2}$. 
Table 1. Attribution of IR main peaks of acids, their basic salts of gadolinium, mixed gadolinium salts and their complexes with a neutral ligand, and Gd-containing polystyrene oligomer

\begin{tabular}{|c|c|c|c|c|c|c|c|c|c|c|}
\hline \multirow[t]{2}{*}{ No } & \multirow[t]{2}{*}{ Compound } & \multicolumn{9}{|c|}{$v, \mathrm{~cm}^{-1}$} \\
\hline & & $\begin{array}{l}v_{a s}(\text { COO- }) / \\
v_{s}(\text { COO- })\end{array}$ & $C=O$ & $\mathrm{C}-\mathrm{O}$ & $\begin{array}{l}\text { C-H } \\
\text { Phenyl } \\
\text { ring }\end{array}$ & $-\mathrm{CH}_{2}-$ & $\mathrm{OH}$ & $\mathrm{C}=\mathrm{CH}_{2}$ & $P=0$ & $\mathrm{P}-\mathrm{C}_{6} \mathrm{H}_{5}$ \\
\hline 1 & $\mathrm{HOOC}^{-}\left(\mathrm{CH}_{2}\right)_{3}{ }^{-} \mathrm{C}_{6} \mathrm{H}_{5}$ & - & 1693 & 1293 & $\begin{array}{l}1603 \\
3063\end{array}$ & $\begin{array}{l}1409 \\
1438 \\
1454\end{array}$ & 3421 & - & - & - \\
\hline 2 & $\mathrm{HOOC}^{-}\left(\mathrm{CH}_{2}\right)_{4}{ }^{-} \mathrm{C}_{6} \mathrm{H}_{5}$ & - & 1692 & 1312 & $\begin{array}{l}1604 \\
3062\end{array}$ & $\begin{array}{l}1438 \\
1454\end{array}$ & 3421 & - & - & - \\
\hline 3 & $\mathrm{HOOC}-\left(\mathrm{CH}_{3}\right) \mathrm{C}=\mathrm{CH}_{2}$ & - & 1738 & 1320 & 2621 & 1462 & $\begin{array}{l}2630 \\
2735\end{array}$ & 1639 & - & - \\
\hline 4 & $\mathrm{HOOC}-\mathrm{C}_{6} \mathrm{H}_{5}-\mathrm{CH}=\mathrm{CH}_{2}$ & - & 1674 & 1318 & $\begin{array}{l}1508 \\
1560 \\
1603\end{array}$ & - & $\begin{array}{c}918 \\
1416 \\
2917\end{array}$ & 1674 & - & - \\
\hline 5 & $\mathrm{Gd}\left(\mathrm{OOC}\left(\mathrm{R}_{1}\right)\right)_{2} \mathrm{OH}$ & $\begin{array}{l}1456 \\
1542\end{array}$ & - & 1308 & $\begin{array}{l}2924 \\
3026 \\
3061\end{array}$ & 1436 & 3435 & - & - & - \\
\hline 6 & $\mathrm{Gd}\left(\mathrm{OOC}\left(\mathrm{R}_{2}\right)\right)_{2} \mathrm{OH}$ & $\begin{array}{c}1457 \\
1543\end{array}$ & - & 1308 & $\begin{array}{l}2925 \\
3025 \\
3062\end{array}$ & 1440 & 3436 & - & - & - \\
\hline 7 & $\underset{\mathrm{H}_{2} \mathrm{Od}\left(\mathrm{OOC}\left(\mathrm{R}_{1}\right)\right)_{2}\left(\mathrm{OOC}\left(\mathrm{R}_{3}\right)\right)}{\operatorname{Gr}}$ & $\begin{array}{l}1416 \\
1546\end{array}$ & - & 1308 & 2922 & 1434 & 3420 & 1640 & - & - \\
\hline 8 & $\begin{array}{c}\mathrm{Gd}\left(\mathrm{OOC}\left(\mathrm{R}_{2}\right)\right)_{2}\left(\mathrm{OOC}\left(\mathrm{R}_{3}\right)\right) \\
2 \mathrm{H}_{2} \mathrm{O}\end{array}$ & $\begin{array}{l}1456 \\
1542\end{array}$ & - & 1314 & 2924 & 1430 & 3438 & 1639 & - & - \\
\hline 9 & $\begin{array}{c}\mathrm{Gd}\left(\mathrm{OOC}\left(\mathrm{R}_{1}\right)\right)_{2}\left(\mathrm{OOC}\left(\mathrm{R}_{3}\right)\right) \\
2 \mathrm{TPPO}\end{array}$ & $\begin{array}{l}1455 \\
1541\end{array}$ & - & 1312 & $\begin{array}{l}3058 \\
2921\end{array}$ & 1430 & - & 1640 & 1186 & 1437 \\
\hline 10 & $\begin{array}{c}\mathrm{Gd}\left(\mathrm{OOC}\left(\mathrm{R}_{2}\right)\right)_{2}\left(\mathrm{OOC}\left(\mathrm{R}_{3}\right)\right) \\
\text { 2TPPO }\end{array}$ & $\begin{array}{l}1438 \\
1543\end{array}$ & - & - & $\begin{array}{l}2951 \\
2919\end{array}$ & 1438 & - & 1636 & 1180 & 1438 \\
\hline 11 & $\begin{array}{c}\mathrm{Gd}\left(\mathrm{OOC}\left(\mathrm{R}_{1}\right)\right)_{2}\left(\mathrm{OOC}\left(\mathrm{R}_{4}\right)\right) \\
2 \mathrm{H}_{2} \mathrm{O}\end{array}$ & $\begin{array}{c}1408 \\
541\end{array}$ & - & - & $\begin{array}{l}2917 \\
3024\end{array}$ & 1430 & 3280 & 1670 & - & - \\
\hline 12 & $\begin{array}{c}\mathrm{Gd}\left(\mathrm{OOC}\left(\mathrm{R}_{1}\right)\right)_{2}\left(\mathrm{OOC}\left(\mathrm{R}_{4}\right)\right) \\
2 \mathrm{TPPO}\end{array}$ & $\begin{array}{l}1437 \\
1541\end{array}$ & - & 1308 & $\begin{array}{l}1588 \\
2916 \\
3051\end{array}$ & & - & 1669 & 1182 & 1437 \\
\hline 13 & $\begin{array}{c}{\left[\mathrm{Gd}\left(\mathrm{OOC}_{(\mathrm{R}}\right)_{2}\left(\mathrm{OOC}\left(\mathrm{R}_{3}\right)\right)\right.} \\
\text { 2TPPO]PS }\end{array}$ & $\begin{array}{l}1455 \\
1541\end{array}$ & - & 1312 & $\begin{array}{l}3058 \\
2921\end{array}$ & 1430 & - & - & 1186 & 1437 \\
\hline 14 & TPPO & - & - & - & 3051 & $\begin{array}{l}1590 \\
1483\end{array}$ & - & - & 1192 & 1438 \\
\hline
\end{tabular}

$\mathrm{R}_{1}=\mathrm{C}_{6} \mathrm{H}_{5}\left(\mathrm{CH}_{2}\right)_{3}-; \mathrm{R}_{2}=\mathrm{C}_{6} \mathrm{H}_{5}\left(\mathrm{CH}_{2}\right)_{4}-; \mathrm{R}_{3}=\mathrm{CH}_{2}=\mathrm{C}\left(\mathrm{CH}_{3}\right)^{-;} \mathrm{R}_{4}=\mathrm{CH}_{2}=\mathrm{CH}\left(\mathrm{C}_{6} \mathrm{H}_{4}\right)-$.

olinium coordination sphere, so water molecules are always present there. This leads to poor quality of the polymer. In the above reaction, the water molecules are replaced by a well-proven neutral ligand. This compound has good complexing properties, its introduction has a favorable effect on the complexes solubility (solubility of complexes with TPPO increases by 3 times compared with hydrocomplexes).

$$
\text { Synthesis }
$$
of oligomer [ $\mathrm{Gd}\left(\mathrm{OOC}\left(\mathrm{CH}_{2}\right)_{3} \mathrm{C}_{6} \mathrm{H}_{5}\right)_{2}\left(\mathrm{OOC}\left(\mathrm{CH}_{3}\right) \mathrm{CCH}_{2}\right) 2$ TPPO]PS was carried out according to the method described in [13] by the Scheme 3.

$$
\left[\mathrm{R}_{2}, \mathrm{R}_{1}-\mathrm{O}_{2}^{\mathrm{O}} \mathrm{Gd}_{2}^{\mathrm{O}-\cdots}\left[\mathrm{H}_{2} \mathrm{O}\right]_{2}^{\mathrm{R}_{4} \mathrm{R}_{3}}+2 \mathrm{O}=\mathrm{P}\right.
$$

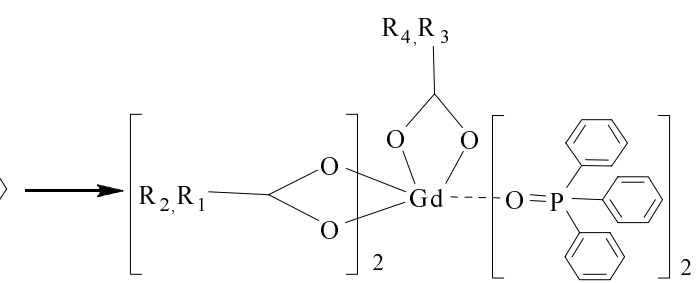

Scheme 3 . 
Table 2. Solubility of gadolinium compounds in toluene

\begin{tabular}{|c|c|c|c||}
\hline \hline \multirow{2}{*}{ No. } & Compound & \multicolumn{2}{|c|}{ Solubility, wt. \% } \\
\cline { 3 - 4 } & & by complex & by gadolinium \\
\hline 1 & $\mathrm{Gd}\left(\mathrm{OOC}\left(\mathrm{CH}_{2}\right)_{3} \mathrm{C}_{6} \mathrm{H}_{5}\right)_{3} 2 \mathrm{TPPO}$ & 42.70 & 5.57 \\
2 & $\mathrm{Gd}\left(\mathrm{OOC}\left(\mathrm{CH}_{2}\right)_{4} \mathrm{C}_{6} \mathrm{H}_{5}\right)_{3} 2 \mathrm{TPPO}$ & 50.0 & 6.53 \\
3 & $\mathrm{Gd}\left(\mathrm{OOC}\left(\mathrm{CH}_{2}\right)_{3} \mathrm{C}_{6} \mathrm{H}_{5}\right)_{2}\left(\mathrm{OOC}_{(}\left(\mathrm{CH}_{3}\right) \mathrm{CCH}_{2}\right) 2 \mathrm{TPPO}$ & 42.50 & 5.90 \\
5 & $\mathrm{Gd}\left(\mathrm{OOC}\left(\mathrm{CH}_{2}\right)_{4} \mathrm{C}_{6} \mathrm{H}_{5}\right)_{2}\left(\mathrm{OOC}\left(\mathrm{CH}_{3}\right) \mathrm{CCH}_{2}\right) 2 \mathrm{TPPO}$ & 50.07 & 6.32 \\
\hline
\end{tabular}

\section{Results and discussion}

The structure of the synthesized compounds was confirmed by the IR spectroscopy; the spectra were recorded on a Spectrum One (Perkin Elmer) Fourier transform IR spectrometer. Table 1 presents the main absorption bands $\left(\mathrm{cm}^{-1}\right)$ in the IR spectra of methacrylate acid, 4-vinylbenzoic acid, 4phenylbutyric acid, 5-phenylvaleric acid, their basic salts (Scheme 1), mixed salts of hydro complexes (Scheme 2), mixed salts of complexes with a neutral ligand (Scheme 3), TPPO, polystyrene Gd-containing oligomer (Scheme 4). The assignment of frequencies in the IR spectra was carried out in accordance with the published data $[14,15]$. IR spectroscopy data for the complexes obtained by us correspond to the assumed compositions.

IR-spectra of acids were compared with basic salts derived from them, which were the starting product for the synthesis of Gd-carboxylates. Also, IR-spectrum of Gdcarboxylates having in their structure two molecules of water were compared with anhydrous Gd-carboxylates containing TPPO as a neutral ligand.

Comparison of the IR spectra of the free acids and their corresponding complexes showed that the absorption bands of $v(\mathrm{C}=\mathrm{O}) / v_{a s}\left(\mathrm{COO}^{-}\right)$are splited and shifted to the low-frequency region at transition from the acid to the Gd-complex (Table 1).

In the IR spectrum of the starting metal salts containing water molecules as a neu-

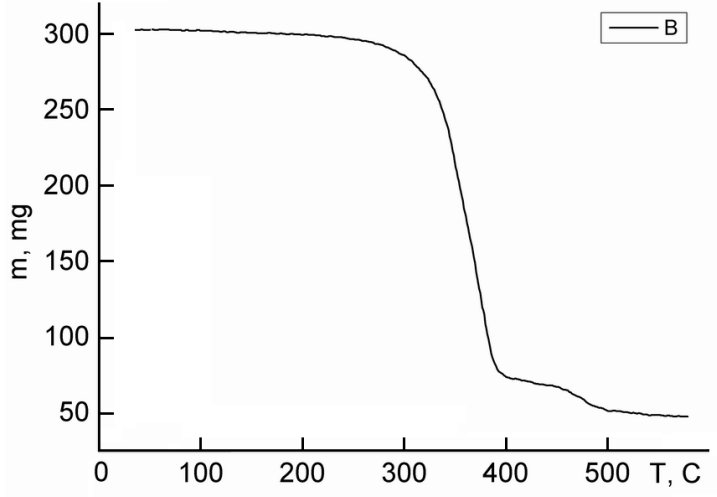

Fig. TGA of the gadolinium complex $\mathrm{Gd}\left(\mathrm{OOC}\left(\mathrm{CH}_{2}\right)_{3} \mathrm{C}_{6} \mathrm{H}_{5}\right)_{2}\left(\mathrm{OOC}\left(\mathrm{CH}_{3}\right) \mathrm{CCH}_{2}\right)$ 2TPPO.

tral ligand (compounds number 7, 8, 11 in Table 1) a broad band is observed in the region $3420,3438,3280 \mathrm{~cm}^{-1}(\mathrm{v}(\mathrm{OH}))$, which corresponds to the coordinated water molecules in the starting Gd-carboxylates.

The FT-IR spectrum of Gd complexes with TPPO shows the absence of the typical broad absorbtion band of $-\mathrm{OH}$ groups $(v(\mathrm{OH}))$ and water molecules $\left(\delta\left(\mathrm{H}_{2} \mathrm{O}\right)\right)$. The result also indicates that the synthesized $\mathrm{Gd}$ complexes do not contain any coordonated water molecules.

The absorption band $v(P=O)$ of Gd-complexes with TPPO is shifted towards lower wave number of 6-10 $\mathrm{cm}^{-1}$ compared with its position in the spectrum of free neutral ligand.

The absorption band $v(P=O)$ of the free neutral ligand is absent in the spectra of
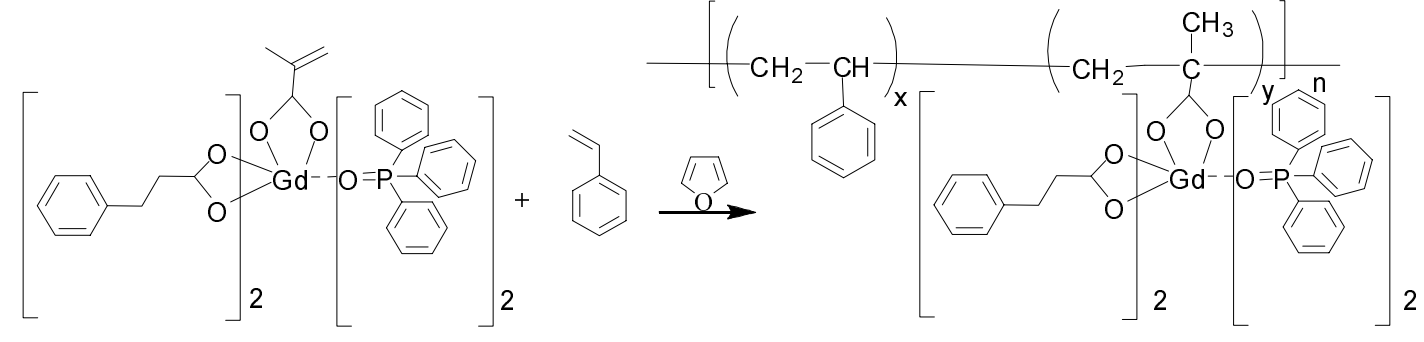

Scheme 4. 
Table 3. Relative light yield $\eta(C)$ of PS samples with different content of gadolinium

\begin{tabular}{|c|c|c|c|c|c|c|c|c|}
\hline \multirow{2}{*}{$\begin{array}{l}\text { No. } \\
\text { PS }\end{array}$} & \multirow[t]{2}{*}{ Compound } & \multirow{2}{*}{$\underset{\%}{\eta(C)}$} & \multicolumn{5}{|c|}{ Mass fraction of $\mathrm{Gd}, \%$} & \multirow{2}{*}{$\begin{array}{l}\text { The composition of PS } 2.0 \\
\text { PPO }+0.1 \text { POPOP }+0.03 \text { AIBN in }\end{array}$} \\
\hline & & & 0.3 & 0.5 & 0.8 & 1.0 & 1.5 & \\
\hline 1 & $\begin{array}{c}\mathrm{Gd}\left(\mathrm{OOC}\left(\mathrm{CH}_{2}\right)_{3} \mathrm{C}_{6} \mathrm{H}_{5}\right)_{2} \\
\left(\mathrm{OOC}\left(\mathrm{CH}_{3}\right) \mathrm{CCCH}_{2}\right)_{2} \mathrm{TPPO}^{-1}\end{array}$ & \multirow{3}{*}{$\begin{array}{l}\text { Light } \\
\text { yield }\end{array}$} & 95 & 88 & 82 & 78 & 75 & Polystyrene \\
\hline 2 & $\begin{array}{c}\mathrm{Gd}\left(\mathrm{OOC}\left(\mathrm{CH}_{2}\right)_{3} \mathrm{C}_{6} \mathrm{H}_{5}\right)_{2} \\
\left(\mathrm{OOC}\left(\mathrm{CH}_{3}\right) \mathrm{CCH}_{2}\right) 2 \mathrm{TPPO}\end{array}$ & & 93 & 86 & 83 & 82 & 78 & $\begin{array}{l}\text { Copolymer of polystyrene and } \\
\text { polymethylmethacrylate }\end{array}$ \\
\hline 3 & 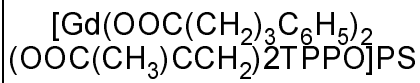 & & 93 & 81 & 75 & 70 & - & Polystyrene \\
\hline
\end{tabular}

the Gd complexes that contain it, which indicates that they do not contain impurities of free neutral ligand. In the FT-IR spectrum, only stretching vibrations of the $\mathrm{P}=\mathrm{O}$ group are shifted, while the location of the absorption band $\delta\left(\mathrm{P}-\mathrm{C}_{6} \mathrm{H}_{5}\right)$ remains practically unchanged. The shift of the absorption band of $v(P=O)$ confirmed the formation of ternary complexes.

The presence of the double bond in the complexes is confirmed by characteristic bands in the region at $1636-1670 \mathrm{~cm}^{-1}$.

The stretching vibration band of the carbonyl group in 4-vinylbenzoic acid, manifested at $1674 \mathrm{~cm}^{-1}$, disappears upon complexation, with two new bands at 1541 and $1437 \mathrm{~cm}^{-1}$ appearing instead in $\mathrm{Gd}\left(\mathrm{OOC}\left(\mathrm{CH}_{2}\right)_{3} \mathrm{C}_{6} \mathrm{H}_{5}\right)_{2}\left(\mathrm{OOC}\left(\mathrm{C}_{6} \mathrm{H}_{4}\right) \mathrm{CH}=\mathrm{CH}_{2}\right)$ 2TPPO complex. These bands correspond to antisymmetric and symmetric vibrations of the $\mathrm{COO}^{-}$group in which both oxygen atoms become equivalent.

Among of the reliable parameter for estimation of stability of REE complexes are their thermographic characteristics. The thermal properties of the Gd-complexes were investigated by thermogravimetric analysics (TGA) on a Mettler TA 3000 (Switzerland) thermoanalytical system. Previously [3] we presented information about the thermal stability of the $\mathrm{Gd}$ complex with phenylbutyric acid containing two molecules TPPO as a neutral ligand. The thermal stability of this compound was in the temperature range $75-80^{\circ} \mathrm{C}$. Figure 1 shows the TGA curve of mixed-ligand gadolinium complex containing unsaturated bond. Analysis of the TGA diagram of the mixed-ligand gadolinium complex showed that it is resistant to heating to $\sim 300^{\circ} \mathrm{C}$. Further heating leads to its decomposition which is complete at $500-600^{\circ} \mathrm{C}$. The final decomposition product is $\mathrm{Gd}_{2} \mathrm{O}_{3}$. The oligomer complex with styrene $\left[\mathrm{Gd}\left(\mathrm{OOC}\left(\mathrm{CH}_{2}\right)_{3} \mathrm{C}_{6} \mathrm{H}_{5}\right)_{2}\left(\mathrm{OOC}\left(\mathrm{CH}_{3}\right) \mathrm{CCH}_{2}\right) 2 \mathrm{TP}-\right.$
PO]PS has the same characteristic of thermal stability. These results indicate that gadolinium compounds have high resistance to temperatures during polymerization, which could provide an opportunity to obtain PS of higher quality.

The obtained results on the solubility of $\mathrm{Gd}(\mathrm{PhB})_{3} 2 \mathrm{TPPO}$ and $\mathrm{Gd}(\mathrm{PhV})_{3} 2 \mathrm{TPPO}$ complexes, their mixed salts and Gd-containing polystyrene oligomer in toluene is presented in Table 2.

As can be seen from Table 2, the solubility of synthesized compounds remains almost unchanged relative to the compounds that do not contain vinyl groups. As for the oligomer, its solubility is not high due to its polymer structure.

Gd-loaded PS were produced by the bulk polimerization. The preparation of plastic scintillator enriched in gadolinium was characterized by the following features: in addition to Gd-containing compounds, activator 2,5-diphenyloxazole (PPO), wavelength shifter 1,4-bis[2-(5-phenyloxazolyl)]benzene (POPOP) and polymerization initiator 2,2'-azodiisobutyronitrile (AIBN) also entered into the composition of PS.

Plastic stintillators were obtained with application of these compounds in various polymer matrices, both on the base of polystyrene and a copolymer of polystyrene with polymethylmethacrylate (molar ratio of comonomers was 60:40, respectively).

Measurements of the light yield of the PS samples were carried out according to the procedure described in [4]. The relative light yield of PS $\eta(C)$ was measured with respect to $\mathrm{PS}$ of the same composition but with zero content of $\mathrm{Gd}$. The results of measurements of the relative light yield $\eta(C)$ of new PS samples using obtained mixed-ligand complexes of gadolinium carboxylates and Gd-containing polystyrene oligomer are shown in Table 3. 
The increase of gadolinium concentration in all sample series leads to a natural decrease of light yield. The highest light yield of the scintillator with the maximum gadolinium concentration is $78 \%$ for PS No.2 (Table 3).

As a result of our work, gadolinium-containing PS with satisfactory scintillation characteristics have been produced. They can be used for dosimetry, for creation of neutron-sensitive detectors, as well as for experiments in high-energy physics.

\section{Conclusions}

Thus, new Gd-containing complexes with unsaturated bonds in constituent molecules were synthesized. Their structure, thermal stability and chemical solubility were studied by IR spectroscopy. It is shown that thermal stability of the complexes increases with introduction of such fragments in the structure of the compound. The spectral and scintillation properties of the new materials were investigated. Introduction of the obtained complexes both in polystyrene and copolymer bases has allowed us to produce PS containing 1.5 wt. $\%$ of gadolinium, with its light yield up to $78 \%$. The use of Gd-containing oligomer in polystyrene matrix has enabled us to produce 1 wt.\% Gdloaded PS with its light yield as high as $70 \%$ with respect to the unloaded one.

\section{References}

1. G.I.Dzhardimalieva, A.D.Pomogailo, Uspehi Khimii, 77, 280 (2008).

2. N.Z.Galunov, V.P.Seminozhenko, Theory and practice of the radioluminescence of organic condensed media, Naukova Dumka, Kiev (1997) [in Russian].

3. A.I.Bedrik, E.S.Velmozhnaya, P.N.Zhmurin et al., Functional Materials, 18, 470 (2011).

4. A.I.Bedrik, E.S.Velmozhnaya, P.N.Zhmurin et al., Inorgan. Mater.: Appl. Res., 5, 339 (2014).

5. A.D.Pomogailo, Kolloid.Zh., 67, 726 (2005).

6. F.R.Kogler, M.Jupa, M.Puchberger, U.Schubert, J.Mater. Chem., 14, 3133 (2004).

7. B.Wu, W/-M.Lu, X.-M.Zheng, Chin.J.Chem., 20, 846 (2002).

8. B.Wu, W/-M.Lu, X.-M.Zheng, J.Coord Chem., 55, 497 (2002).

9. B.Wu, W/-M.Lu, X.-M.Zheng, J.Chem.Krystallogr., 33, 203 (2003).

10. B.Wu, W/-M.Lu, X.-M.Zheng, Transition Met. Chem., 28, 323 (2003).

11. A.I.Bedrik, E.S.Velmozhnaya, P.N.Zhmurin, Patent Ukraine, 98259 (2012).

12. S.V.Eliseeva, O.V.Mirzov, L.S.Lepiev et al., $J$. Inorgan. Chem., 50, 596 (2005).

13. Q.D.Ling, Q.J.Cai, E.T.Kang et al., J.Mater. Chem., 14, 2741 (2004).

14. K.Nakamoto, IR Specta and Raman Spectra of Inorganic and Coordination Compounds, Wiley, New York (1986).

15. L.A.Kazitsyna, N.B.Kupletskaya, Application of Ultraviolet, Infrared and Nuclear Magnetic Resonance Spectroscopy in Organic Chemistry, Vysshaya Shkola, Moscow (1971) [in Russian]. 